\title{
Research Article \\ Determinants and Directions of Evolution of Intermunicipal Cooperation Forms - From the Perspective of 30 Years of Experience in the Creation of Municipal Associations in Poland
}

\author{
Malgorzata OFIARSKA \\ University of Szczecin, Szczecin, Poland \\ https://orcid.org/0000-0001-5311-0201 \\ malgorzata.ofiarska@usz.edu.pl
}

Received date:24 March 2021; Accepted date: 2 August 2021; Published date: 28 January 2022

Copyright (C) 2022. Malgorzata OFIARSKA. Distributed under Creative Commons Attribution 4.0 International CC-BY 4.0

\begin{abstract}
The institution of intermunicipal cooperation has been studied in the world literature from different perspectives, from the motivation for undertaking cooperation, to the presentation of institutional arrangements, to the results of cooperation. This study presents the status and major directions of European research. Against this background, the premises, dynamics and directions of development of intermunicipal cooperation in Poland are presented. Using a dogmatic-legal, historical-legal and empirical method, the study examines and evaluates municipal associations, which have been established in Poland for 30 years and represent the most durable and formalized form of such cooperation. They are created for the purpose of joint implementation of public tasks, the results of which are aimed at meeting the basic needs of residents. The thesis has been formulated that intermunicipal cooperation in the form of associations is a mechanism of voluntary and bottom-up correction of the method used by the legislator to divide public tasks between local government units and financial resources allocated to them for their implementation. The use of the legal form of a municipal association as an instrument for the auxiliary and secondary distribution of tasks and responsibilities makes it possible to correct the statutorily defined division of tasks independently by interested units, without the need to change the arrangement of tasks through legislative work. Municipal associations are a factor potentially dynamizing the static (statutorily defined) distribution of public tasks and competencies. They coexist alongside the functioning degrees of the state's territorial division and complement the structures of public administration. Their creation promotes the development of a region and generally contributes to the socio-economic and civilization prosperity of the larger area of the state. As a result, the creation of municipal associations was considered an alternative to making another costly reform of the state's territorial division.
\end{abstract}

Keywords: determinants of intermunicipal cooperation, intermunicipal cooperation, intermunicipal union, municipal union

Cite this Article as: Malgorzata OFIARSKA (2022)," Determinants and Directions of Evolution of Intermunicipal Cooperation Forms - From the Perspective of 30 Years of Experience in the Creation of Municipal Associations in Poland", Journal of Eastern Europe Research in Business and Economics Vol. 2022 (2022), Article ID 349212, DOI: 10.5171/2022.349212 


\section{Introduction}

The cooperation of local government units (otherwise referred to as municipal or intermunicipal cooperation, IMC) in various aspects is the subject of research in the doctrine. It is a permanent element of modern public administration and functions in countries with different levels of regional development. However, its genesis, organizational and legal features as well as dynamics and directions of development are different. Currently, in individual European countries in the field of cooperation of local government, there are comprehensive, but at the same time different legal solutions, and, therefore, also different reflections and assessments of its effects. This phenomenon does not apply to all countries to the same degree, and the very evolution of legislative solutions in the field of intermunicipal cooperation does not show the same intensity of cooperation in this respect everywhere. This is mainly due to the degree of territorial fragmentation, different paths of evolution and organization of local government, different scope of tasks performed by local government units, tradition and experience of local government cooperation, the degree of decentralization of competences to perform public tasks and the methods of their financing, as well as the level of respect for principles of adequacy of tasks and financial resources necessary for their performance and the models of sources of income used by local government units. Although cooperation is a common practice in European countries, the research problem requires further research (Swianiewicz, Teles, 2019, p. 120; Teles, 2016 , p. 87-88). The aim of the study is to show that the cooperation of local government units in Poland in the form of unions may constitute a mechanism of an appropriate, voluntary and bottom-up correction of the method of division of tasks applied by the legislator between such units and the resources assigned to them necessary for their implementation. Polish, more than 30 years of experience in performing public tasks in the form of communal unions may constitute a good model for other European countries, especially those outside the structures of the European Union, and those considering possible accession. They can be used in the adopted concepts relating to the model and structure of local self-governments in these countries or possible reforms of existing self-governments. For countries with greater local government traditions, Polish experience can be used for comparative research and analysis of the effectiveness of solutions adopted in Poland since 1990, after a nearly 50-year break in the functioning of the competent local government. It should be emphasized that individual units of local self-government, for objective reasons, are not self-sufficient and prepared to independently carry out all assigned tasks. The cooperation of these units is therefore necessary and takes more or less institutionalized forms. One of such forms are associations of local government units, which arise as a result of grassroots and voluntary initiatives. As a rule, unions are formed by local government units from a specific compact area. In this way, they constitute a good social and material base for solving problems of regional importance. It can be assumed that the creation of unions of local government units is not only a form of cooperation of these units in the implementation of their tasks, but also supports the development of a given region and generally contributes to the socio-economic and civilization prosperity of a larger area of the state. At the same time, it enables closer cooperation with regions from other countries, in particular from neighboring countries. A significant added value is the increase in social awareness of local and regional communities about the need to engage in public affairs.

There are legal, economic and business problems associated with the functioning of unions of local government units. This determined the use of appropriate research methods. Using the dogmatic-legal method, the basic elements of the legal structure of

Malgorzata OFIARSKA, Journal of Eastern Europe Research in Business and Economics, DOI: $10.5171 / 2022.349212$ 
the union of local government units were established, as well as the interpretation of legal provisions and their exegesis. This made it possible to examine the legal essence of the institution of the union of local government units. In order to present the evolution and main trends in the development of associations of local government units in Poland, the historicallegal method was used to examine the scope and context of changes in the applicable legislation. Using the empirical method, numerical data were presented that illustrate the most important effects of the functioning of unions of local government units in Poland, including the dynamics of the created unions in 20152020, their income, revenues, expenses and outlays. This illustrates the scale of the phenomenon of cooperation between Polish local government units and the evolutionary trends taking place in this respect. The study also uses official sources of information, such as registers of associations of local government units and reports on the implementation of budgets by local government units and their unions. The hypothesis about the necessity to create legal solutions enabling local government units to undertake and develop forms of cooperation, including through the creation of relationships that constitute the most durable and formalized form of cooperation in local government, has been questioned. Cooperation is an objective necessity resulting from the different levels of development of individual units of local government, their different civilization potential, conditioned by population resources, material components, infrastructure, access to natural resources and the provision of income sources of different efficiency. Often, it is also the scope and nature of the tasks that will decide about undertaking a specific form of cooperation. Some of them, for reasons of economic efficiency, should be performed jointly, while their possible independent implementation by a local government unit leads to an unjustified increase in costs and excessive expenditure financed from public funds.

\section{Literature Review}

The problem of cooperation between local government units, mainly municipalities, is studied in many countries. In the world literature, inter-municipal cooperation has been analyzed from various perspectives, ranging from the motivation for undertaking cooperation, through the presentation of institutional solutions, to the results of cooperation. Not only were the institutional arrangements and the scale of inter-municipal cooperation in one country investigated, but also identify the main differences and similarities in two countries. The results of comprehensive comparative studies were also occasionally presented, including the analysis of the institution of inter-municipal cooperation in several countries (Hulst, Montfort, 2007; Swianiewicz, 2011; Hulst, Montfort, 2012; Swianiewicz, Teles, 2019). In European studies, most attention has been so far devoted to inter-municipal cooperation in France (Perrin, 2001; Bernard-Gélabert, 2003; Girardon, 2008; Christiany, Méhaignerie, 2008; Aubelle et al., 2015) and Germany (Rolfes, Volkert, 1992; Zielke, 1993; Groud, 2003), and less in other European countries - Switzerland (Steiner, 2001; Steiner, 2002; Steiner, 2006), Austria (Matschek, 2011), Italy (Baldini et al., 2009; Marotta, Bolgherini and Casula, 2018), Belgium (de Bruycker, 2000), the Netherlands (Haaren-Dresens, 2000), Spain (Font i Llovet, 2020), Portugal (Montalvo, 2020) and in the Scandinavian countries (Hilborn, Riberdahl, 2000). In the last decade, the causes and determinants as well as various aspects of the organization, functioning and impact of inter-municipal cooperation, were analyzed, including in: the Czech Republic (Sedmihradská, 2018; Bakoš et al., 2020), Slovakia (Grešová, 2016), Croatia (Koprić, Škarica and Milošević, 2015), Slovenia (Rakar, Tičar and Klun, 2014, 2015; Pevcin, 2018), Estonia (Mäeltsemees, Lõhmus and Ratas, 2013), Ukraine (Popova, Kononenko, 2018; Tolkovanov, 2017) as well as Albania (Kurti, Lame, 2014), candidate for the European Union. The essence and legal nature of inter-municipal cooperation (Bolgherini, Messina, 2014; Swianiewicz,

Malgorzata OFIARSKA, Journal of Eastern Europe Research in Business and Economics, DOI: $10.5171 / 2022.349212$ 
Teles, 2018) was studied and the forms of inter-municipal cooperation were classified (Hulst, Montfort, 2012; Tavares, Feiock, 2018). The costs and the effects (Arntsen, Torjesen and Karlsen 2020) were analyzed, including financial inter-municipal cooperation (Allers, Ommeren, 2016; Dollery et al., 2020). An important part of the scientific discussion is devoted to the analysis of the importance of voluntary inter-municipal cooperation as the first stage (Fraanje, Herweijer, 2013; Stehen, Wayenberg, 2016) or alternatives to the merger (merger) of small municipalities (Thurmaier and Wood 2004; Hertzog 2010; Bel, Warner, 2015; Ježek, Kaňka 2015; Cornea, 2017; Wollman, 2017). The issue of inter-municipal cooperation is not only the subject of interest in European literature. Similar studies are also carried out e.g., in the United States (Warner, Austin and Yunji, 2020), Canada (Sancton, James and Ramsay, 2000; Spicer, 2015) and in Latin America (Endlich, 2018; Yurisch, Soto and Fuenzalida, 2019). Comprehensive analyzes of the cooperation of local government units and their development prospects are also prepared by international institutions, such as the Council of Europe $(2007 ; 2015)$ or the United Nations Development Program (2010). In Polish doctrine, the cooperation of local government units is of interest both in legal sciences (Ofiarska, 2008; Dolnicki, 2018), as well as in economics and finance (Zeman-Miszewska, 2016; Zioło, Oliwa, 2016; Łukomska, Szmigiel-Rawska, 2019), management sciences (Kogut-Jaworska, Smalec, 2018) and political science (Szczegielniak, 2017). Research is conducted on the premises, barriers and results of cooperation (Gendźwiłł, Krukowska and Lackowska, 2019) and the principles of creating, organizing and functioning of public-law forms of cooperation as a tool for local and regional development (Kołsut, 2015; Ofiarska, 2017; Jaworska-Dębska, 2019). The last decade has been dominated by research on the emerging new forms of cooperation in local government (Lisowski, 2017; Ofiarska, 2020) and the search for forms of cooperation appropriate to the performance of public tasks in metropolitan areas (Danielewicz, 2013; Szlachetko, Gajewski, 2016; JaworskaDębska, 2017; Ofiarska, Ofiarski, 2021).

The lapse of 30 years since the restitution of local government in Poland justifies the presentation and assessment of the adopted concept of the union of local government units as the most advanced and institutionalized form of cooperation, used for the implementation of public tasks, especially in the sphere of public transport, environmental protection, municipal waste management, water and sewage management (Kiełbus, Ziemski, 2020). This problem has a multifaceted dimension, as evidenced by, inter alia, legislative initiatives undertaken over three decades or attempts to adopt systemic solutions for large cities and the surrounding communes.

\section{Unions of local government units in Poland}

The union of local government units (municipal union) is considered the basic public-law institutional form of cooperation of local self-government units (in Poland, the union can only be created by local government units - communes and poviats, such power has not been granted to regional self-government units voivodships). Its original legislative concept has undergone a specific evolution.

Establishing unions by communes was made possible in 1990. The act of March 8, 1990, on commune self-government, standardized the principles of establishing the system and only partially the material foundations of the functioning of intercommunal unions. The principle was adopted that unions are formed voluntarily in order to jointly perform public tasks agreed by communes, which the union will perform on its own behalf and on its own responsibility. The union is an organizational unit of the public finance sector with all the consequences resulting from its financial and legal status. For obvious reasons, some of the funds of municipal unions come from local government units that are their founders and members (e.g., in the form of

Malgorzata OFIARSKA, Journal of Eastern Europe Research in Business and Economics, DOI: $10.5171 / 2022.349212$ 
membership fees and other contributions made by union members, subsidies transferred from the budgets of local government units to municipal unions). On the other hand, separate sources of income for a municipal union are usually: income from the trade union's economic activity, income from its enterprises or shares in companies and other economic ventures, income from the sale of union assets, funds obtained from aid programs, including European Union funds.

The legislator referred to this concept of a relationship in the context of the state system reform in 1998 and, following it, created a supra-communal unit of local self-government (poviat). In the act of June 5, 1998, on poviat self-government, he adopted juridical solutions regulating the principles of establishing the system and fragmentary material foundations for the functioning of poviat associations.

In the years 1990-2020, the provisions of the above-mentioned acts relating to unions with the participation of local government units were amended six times (in 1995, 1996, 2001, 2002, 2015 and 2016). There were various motives for amending self-government system statutes and their significance. First, legal solutions were adopted which enabled and then facilitated the creation of unions in order to implement public tasks, including those of a specific strategic importance (e.g., in the areas of large cities and surrounding communes). Also, changes of a pro-quality nature were introduced, clarifying the provisions which raised interpretation doubts. Solutions were adopted to simplify and streamline the procedure for establishing, registering and liquidating unions. The legislation was amended in stages in order to ensure the consistency of the solutions contained therein and to gather the necessary experience in order to choose the right direction for the next reforms.

Some changes took into account the experience of local government to date in the functioning of unions with the participation of communes and poviats.
New solutions were introduced aimed at improving the organization of performing public tasks by local government and adjusting organizational structures and work organization to local needs and possibilities. Recognizing the specificity and problems of functional areas, mainly metropolitan areas, in the implementation of public tasks (including the lack of proper coordination of tasks of strategic importance, such as spatial planning, public transport), the possibilities of cooperation in such areas were expanded in 2016, enabling the creation of unions with the participation of communes and poviats (poviat and commune associations). At the same time, the rules and procedures for transforming associations of communes and associations of poviats into poviatcommune unions have been regulated. The legal basis for the creation of a selfgovernment shared service center and the creation of inter-commune unions, poviat unions and poviat-commune unions in order to jointly service them, have been created (Act of June 25, 2015 amending the act on municipal self-government and certain other acts).

The concept of a union of local government units was repeatedly referred to as part of the work aimed at adopting statutory solutions regulating the legal status of metropolitan areas, including the act on metropolitan unions (Act of October 9, 2015, on metropolitan unions) (it was repealed after one-year period of validity) and the current act of March 9, 2017, on metropolitan unions in the Śląskie Voivodeship and in subsequent bills of acts on metropolitan unions proceeded in the legislative process (Ofiarska, 2018).

\section{Quantitative structure of associations of local government units and their budgets}

The quantitative and valuable development of cooperation in local government in the form of unions is presented on the basis of information systematically collected by the bodies keeping the trade union registers and the bodies supervising their financial activities. 


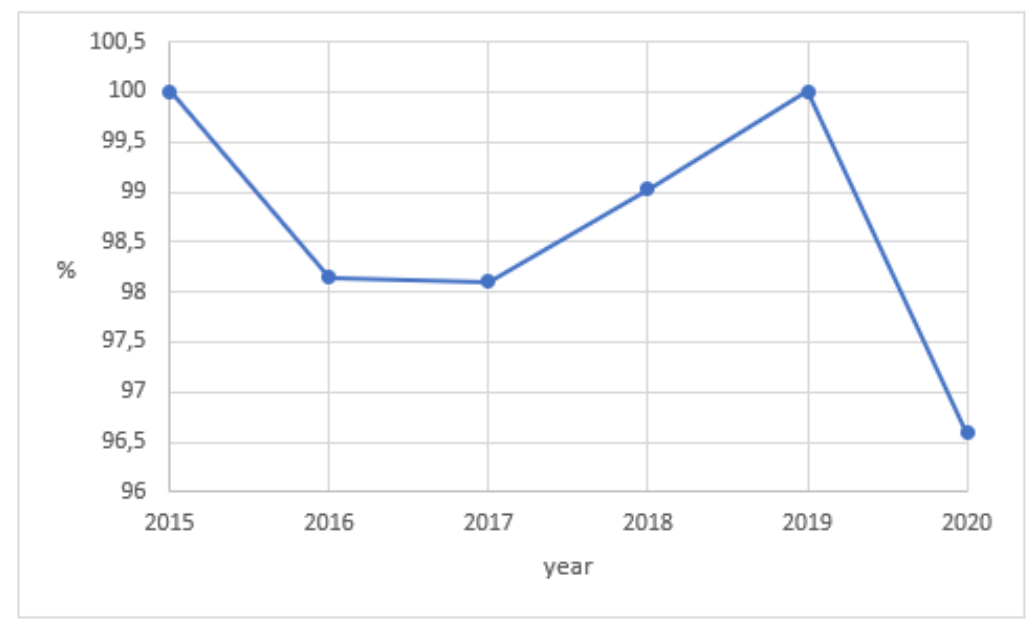

Fig. 1: Dynamics of intermunicipal unions in 2015-2020

Source: Author's own study based on the register of intermunicipal unions

The information contained in the register of inter-commune unions, as of December 31,2020 , shows that 314 unions have been entered into it so far (3 of them were transformed into poviat-commune unions, and 24 were liquidated). A characteristic phenomenon was initially the rapid increase in the number of inter-municipal unions. The dynamics of this phenomenon have clearly decreased over time. The territorial distribution of inter-communal unions is not even (the fewest unions were formed by communes from the following voivodeships: Opolskie, Podlaskie, Pomorskie, while most unions were formed by communes from the following voivodeships: Wielkopolskie, Małopolskie, Mazowieckie, Dolnośląskie). This proves the different intensity of this form of cooperation in individual voivodeships.

Inter-communal unions, usually established for an indefinite period, are used for the permanent joint performance of public tasks belonging to the communes that create it, and then transferred to the union. Multitasking relationships predominate. The scope of tasks carried out by inter-municipal unions has changed. Initially, the unions mainly carried out tasks in the field of: environmental protection, water management, water supply and waterworks, sewage system, municipal sewage disposal and treatment, landfills and municipal waste disposal, electricity, heat and gas supply, as well as public transport (these tasks are still carried out by the unions). With the passage of time, the tasks related to the development of tourism, sport and recreation have also become the subject of interest of the unions; construction and modernization of technical and social infrastructure, initiatives for the development of the information society. 


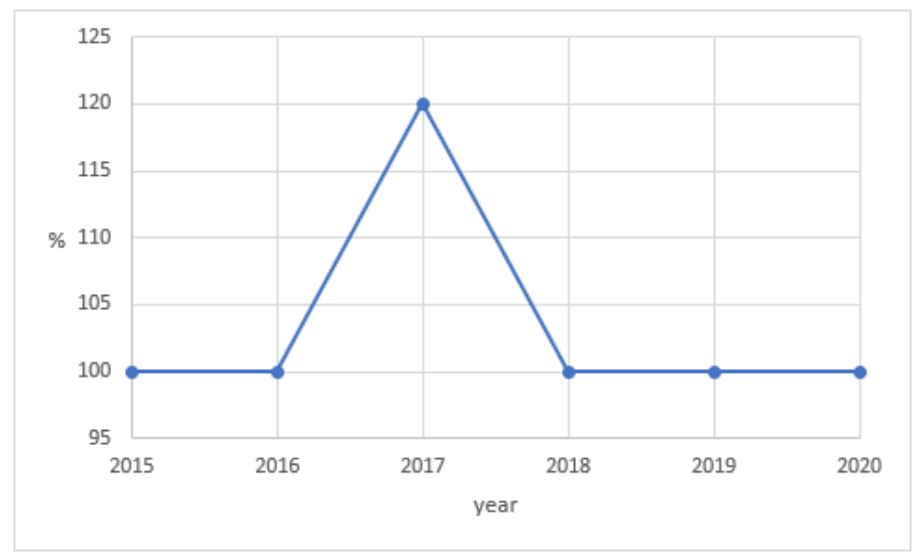

Fig. 2: Dynamics of poviat unions in 2015-2020

Source: Author's own study based on the register of intermunicipal unions

As at December 31, 2020, 7 unions were entered in the register of poviat associations, 1 of which was liquidated in 2012. The remaining unions of poviats were established for an unlimited period, mainly to carry out tasks in the field of digitization of databases and collective passenger transport in the area of member poviats.

Compared to the number of intermunicipal unions, the cooperation of poviats in the form of unions is marginal (in 2021 in
Poland there were 314 poviats and 66 cities with poviat rights). The small number of poviat unions results from the fact that most of the most important public tasks of a local nature have been delegated for implementation by inter-communal unions. Moreover, poviats, in terms of area, are not units operating next to communes, because within the boundaries of a given poviat there are areas of several or a dozen or so communes, and the inhabitants of communes are also residents of a given poviat.

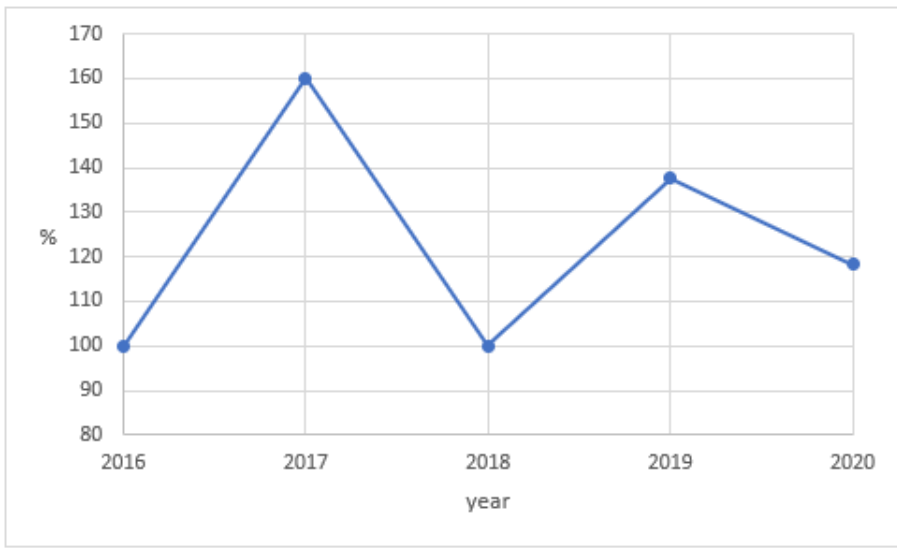

Fig. 3: Dynamics of poviat and commune unions in 2016-2020

Source: Author's own study based on the register of poviat and commune unions

Malgorzata OFIARSKA, Journal of Eastern Europe Research in Business and Economics, DOI: $10.5171 / 2022.349212$ 
A separate category is poviat and commune unions, of which there were 13 in the register as of December 31, 2020, with as many as 8 unions performing tasks in the field of public collective transport, as well as providing joint service for poviat and commune organizational units, activation of the local labor market, economic and tourism development, environmental protection and pro-ecological activities.
The possibility of creating poviat-commune unions is an opportunity to tighten the cooperation of territorial self-government units of various levels (commune and poviat) and to create mini-regions.

The values of their budgets testify to the scope of the activities conducted by the unions. The assessment covered mainly the four main items making up their budgets: income, revenues, expenses and outlays.

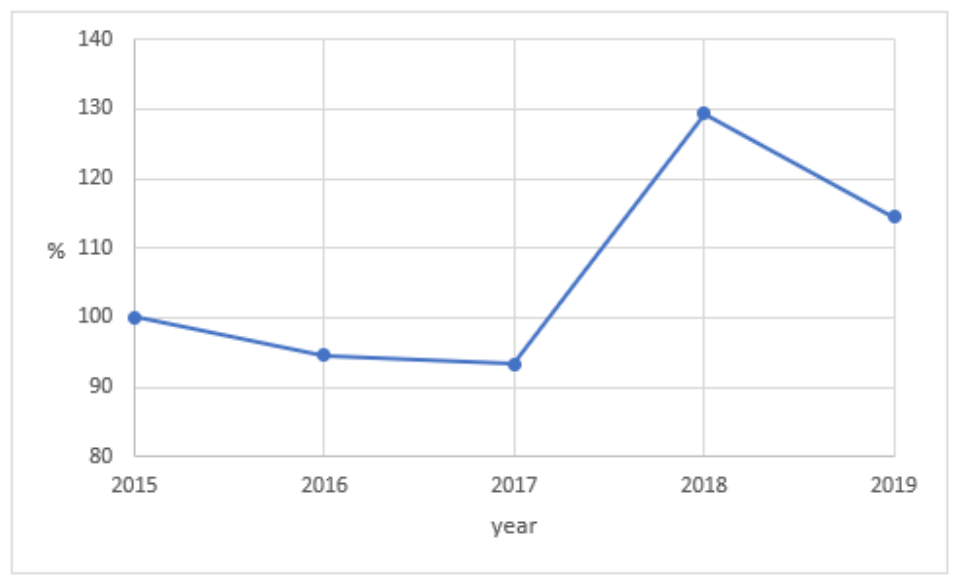

Fig. 4: Income dynamics of associations of local government units in 2015-2019

Source: Author's own study based on reports on the activities of regional accounting chambers and budget implementation by local government units

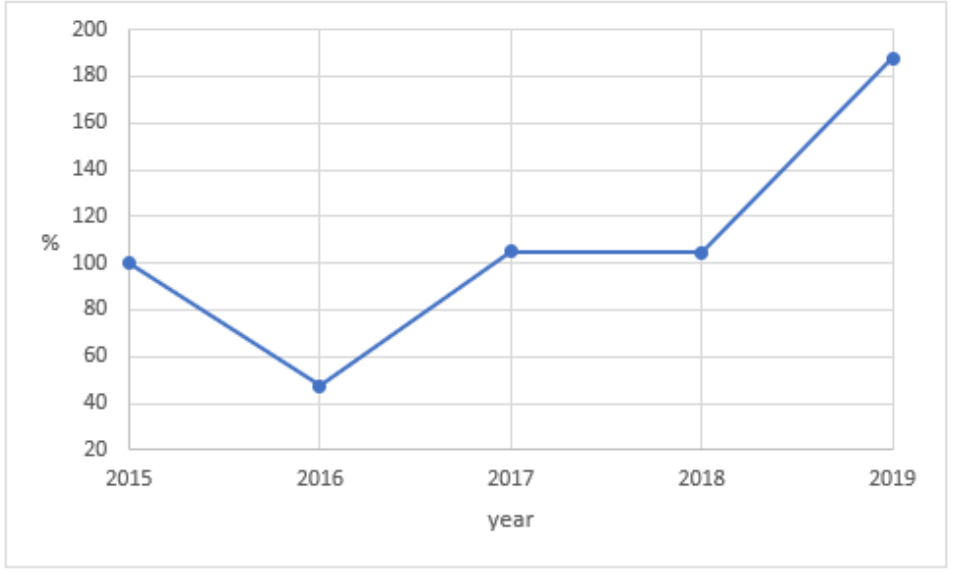

Fig. 5: Revenue dynamics of associations of local government units in 2015-2019

Source: Author's own study based on reports on the activities of regional accounting chambers and budget implementation by local government units

Malgorzata OFIARSKA, Journal of Eastern Europe Research in Business and Economics, DOI: $10.5171 / 2022.349212$ 
The temporary decline in income and revenues of associations of local government units in 2016-2017, compared to 2015 , was mainly determined by lower revenues from special-purpose subsidies related to the implementation of programs financed from foreign sources, which was due to the fact that revenues from reimbursement after the implementation of projects were financed from foreign funds. Similar reasons influenced the development of revenues, especially from loans and credits taken by unions. The reduced scope of liability of the unions resulted in less pressure to take out new credits and loans necessary to cover the own contribution necessary in the procedure of applying for EU funds. Since 2018, revenues have been systematically increasing, mainly due to the received targeted subsidies related to the implementation of programs financed from foreign sources, which are covered by the EU financial perspective for 2014-2020. For the same reason, there is an increase in the unions' revenues (in the form of credits and loans) necessary to cover the own contribution in subsequent investment projects.

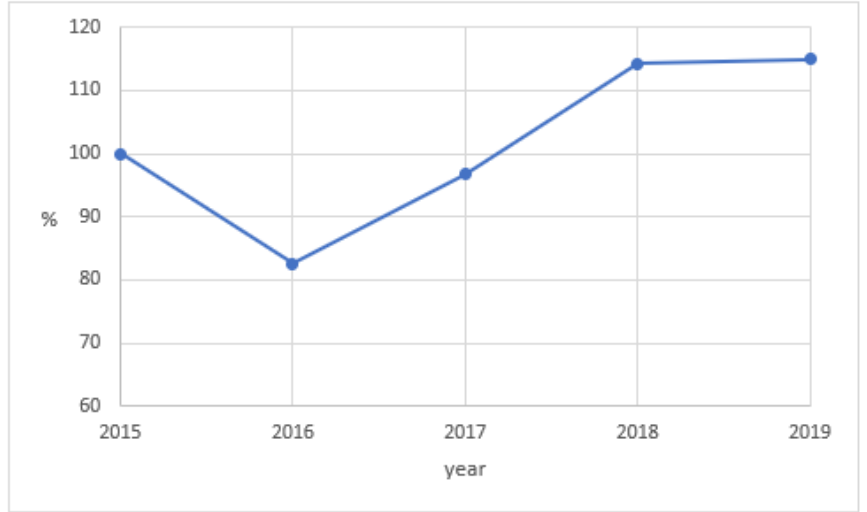

Fig. 6: Expenditure dynamics of unions of local government units in 2015-2019

Source: Author's own study based on reports on the activities of regional accounting chambers and budget implementation by local government units

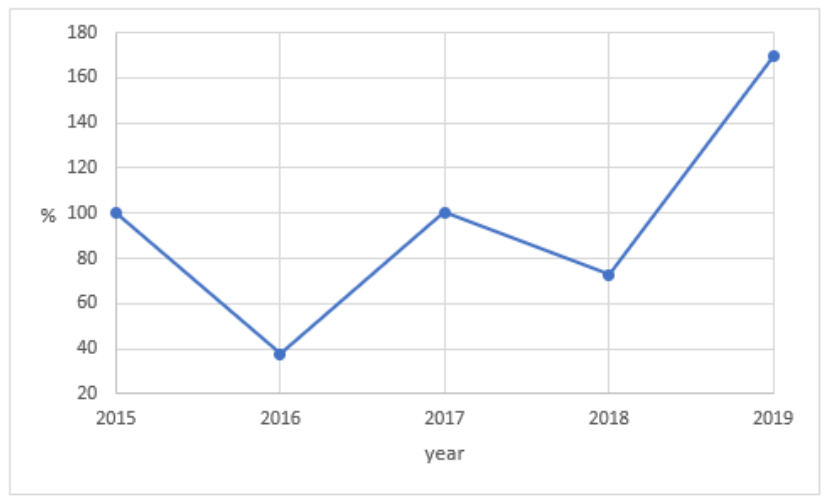

Fig. 7: Outgoings' dynamics of unions of local government units in 2015-2019

Source: Author's own study based on reports on the activities of regional accounting chambers and budget implementation by local government units

Malgorzata OFIARSKA, Journal of Eastern Europe Research in Business and Economics, DOI: $10.5171 / 2022.349212$ 
The expenditure and outgoings of unions of local government units clearly decreased in 2016-2017 compared to 2015. This was mainly due to the limitation of the scope of tasks carried out with the participation of foreign funds, as most of the projects financed from EU funds from the previous 7-year period were completed. As part of the next 7-year financial perspective, launched in 2014, adequate time was required to implement new projects. Completion of planning, application and public procurement procedures resulted in a significant increase in expenditure in 2018-2019, including those resulting from price increases and inflation. The increase in outgoings was mainly due to the obligation to repay the debt incurred in previous years.

For several years, there has been only one metropolitan union in Poland, which has a different status than other associations of local government units. The nature of the tasks performed and the sources of their financing are similar to those performed in municipal unions.

\section{Final Thoughts}

The concept of cooperation adopted in Poland, based on the voluntary principle, has evolved through successive reforms made in the organization and scope of tasks of local government. The legislator, noticing the undoubted advantages of supporting the development of institutional forms of cooperation and their positive impact on the processes of improving the forms of effective resolution of the most important problems in the local and regional dimension, successively expanded the catalog of tasks and spatial possibilities of undertaking cooperation in the form of unions. In 1990, this form was made available only to communes, and since 1999 also to poviats. First, a characteristic trend was unnamed unions (inter-commune, poviat), and only since 2016, it was possible to create bipartite unions (poviat-commune). The establishment of new local government units (counties) and regional government units (provinces self-government units) on 1 January 1999 did not repeal the existing legal solutions regulating the principles of inter-municipal cooperation. A reverse tendency can be identified.

The unification of the conditions and tasks of all local government units of the same degree, carried out in the course of determining the systemic and financial aspects of the functioning of local government, the successive transfer from the sphere of government administration of subsequent tasks to be performed by local government, and even taking into account immediate needs (the need to secure the current needs of the state budget in period of a serious crisis of public finances at the turn of the twentieth and twenty-first centuries), constituted premises for the growing interest on the part of local government units in the instruments of correction of the legal solutions adopted in this area. Especially that the transfer of subsequent tasks to be performed in the local government from the sphere of government administration often took place without prior examination of the possibility of their implementation by the local government and without proper securing of the financial resources necessary for their implementation, and even with the simultaneous weakening of the income potential of local government units by making unfavorable changes in the legal structure of certain local public levies being their primary sources of income.

The low efficiency of the sources of income of local government units is an important reason determining the necessity to develop various forms of intercommunal cooperation. Particular local government units can have the same categories of sources of income; however, they differ in the level of efficiency in management of those, which is usually related to different operating conditions of these units. Frequent amendments to tax laws, and in particular the introduction of new tax exemptions and tax reliefs, make the negative trends in this area permanent. In the light of the standards set by the

Malgorzata OFIARSKA, Journal of Eastern Europe Research in Business and Economics, DOI: $10.5171 / 2022.349212$ 
European Charter of Local SelfGovernment, the structure of poviats' sources of income in Poland seems defective, since they have not been equipped with their source of income from the local taxes, and the income resulting from the local fees is of a marginal importance in supplying their budgets. This led to the emergence of new forms of cooperation. Local government taking over tasks from the government administration, quantitative and qualitative growth as well as the diversification, size and complex nature of some public tasks carried out by local government, the emergence of new needs of local communities, constantly growing costs of operation, limited financial resources and other reasons led to the municipal unions (mainly intermunicipal unions), being used as instruments for auxiliary and secondary allocation of tasks and competences. The use of the legal form of the union enables interested units to correct the statutory division of tasks on their own, without the need to change the arrangement of tasks through legislative work. As a result, they were considered an alternative to another costly reform of the territorial division of the state. They constitute a factor that potentially dynamizes the static, i.e., statutorily defined, distribution of public tasks and competences, and they complement the structures of public administration and coexist alongside the operating degrees of territorial division of the state. This form of cooperation in various situations may be occasionally or even in the longer term combined with other forms of cooperation (unions are entitled to conclude agreements and to grant and receive material and financial aid). The position of municipal unions in the Polish local government is already firmly established. However, there is no systemic and comprehensive regulation of them. The concept of a complete and internally coherent regulation of systemic, organizational, functional and financial matters of associations of local government units, has not even been prepared. First of all, it is necessary to create a stable legal basis for their functioning and to abandon solutions that seem to be unfinished or temporary (e.g., consisting in referring to the appropriate application of financial management regulations to the principles of financing municipal unions, forming a union of communes and poviats). Additionally, the development of this form of cooperation should be supported by appropriate financial and legal solutions. Municipal unions could be equipped with stable sources of income, and in the case of implementing tasks of significant importance for the region or a larger area, they could receive subsidies or grantss from the state budget (e.g., if in this way significant problems in the field of regional passenger rail transport were resolved or disaster risk level).

The results of the current functioning of municipal unions in Poland, collected in the course of the research, may be useful, especially in the countries of Central and Eastern Europe, where the processes of decentralization and the related reforms of local governments have not yet been completed. Opening the cognitive perspective to solutions used in other countries is an objective necessity. The institutional and financial crisis caused by the COVID-19 pandemic will force the use of such forms to meet the basic needs of residents, which will create conditions for achieving optimal results with significantly limited human and material resources. The reconstruction of socio-economic ties also requires the intensification of forms of cooperation in the local dimension, but translating into regional development, also involving regions from different countries. The extraordinary current situation justifies the need for in-depth research on solutions used in various countries in order to learn from specific foreign patterns and their assimilation by the public authorities of individual countries.

\section{Foot Note}

The text was presented (as a virtual presentation) at the 37 th International Business Information Management Association Conference (IBIMA) and published as Polish Experience From 30 Years of Functioning of Associations of

Malgorzata OFIARSKA, Journal of Eastern Europe Research in Business and Economics, DOI: $10.5171 / 2022.349212$ 
Local Government Units (Municipal) As A Formal and Material Basis for Regional Development, [in:] Khalid S. Soliman (ed.), Innovation Management and information Technology impact on Global Economy in the Era of Pandemic: Proceedings of the 37th International Business Information Management Association Conference (IBIMA) 30-31 May 2021, Cordoba, Spain, ISBN 978-0-9998551-6-4, pp. 7555-7563.

\section{References}

- $\quad$ Act of March 8, 1990 on commune self-government (Journal of Laws of 2021, item 1372).

- $\quad$ Act of June 5, 1998 on poviat selfgovernment (Journal of Laws of 2020, item 920, as amended).

- Act of June 25, 2015 amending the act on municipal self-government and certain other acts (Journal of Laws, item 1045, as amended).

- Act of October 9, 2015 on metropolitan unions (Journal of Laws, item 1890, as amended).

- Act of March 9, 2017 on the metropolitan union in the Silesian Voivodeship (Journal of Laws of 2021, item 1277).

- $\quad$ Allers, M.A. and van Ommeren, B. (2016), 'Intermunicipal cooperation, municipal amalgamation and the price of credit', Local Government Studies, 42/5, 717-738.

- Arntsen, B., Torjesen, D.O. and Karlsen T.I (2020), `Associations between structures, processes and outcomes in inter-municipal cooperation in out-of-hours services in Norway: A survey study`, Social Science \& Medicine, 258.

- $\quad$ Aubelle, G., Pélissard, P.B., Gibert P. and Pélissard J. (2015), La Commune Nouvelle, BergerLevrault, Paris.

- Bakoš, E., Němec, D., Hrůza, F. and Mix, T. (2020), `Emerging Topics on Inter-municipal Cooperation in the Czech Republic: Policy Networking, Regionalization and Financial Indicators', Lex Localis -
Journal of Local Self-Government, 18/3, 579-602.

- $\quad$ Baldini, G., Bolgherini, S., Dallara, C. and Mosca, L. (2009), Unioni di Comuni: le sfide dell'intercomunalità in EmiliaRomagna, Istituto Carlo Cattaneo, Bologna.

- Bel, G. and Warner, M. (2015), 'Inter-Municipal Cooperation and Costs: Expectations and Evidence', Public Administration, 93/1, 52-67.

- Bernard-Gélabert, M. Ch. (2003), L' intercommunalité, Dexia LGDJ, Paris 2003.

- Bolgherini, S. and Messina, P. (2014), Oltre le province. Enti intermedi in Italia e in Europa, Padova University Press, Padova.

- Christiany, D. and Méhaignerie, P. (2008), Pratique du droit de l'intercommunalité: communautés, syndicats, transferts et gestion de compétences, Dexia, Paris.

- Cornea, S. (2017), 'Inter-Municipal Cooperation: An Alternative Solution for The Amalgamation Projects?', Journal of Danubian Studies and Research, 7(1), 109121.

- Council of Europe, (2007), Good practices in intermunicipal cooperation in Europe. Report of the European Committee on Local and Regional Democracy, Strasbourg.

- Council of Europe, (2015), Mapping the obstacles to intermunicipal to cooperation in Eastern Partnership countries, Strasbourg.

- Council of Europe, United Nations Development Programme, (2010), Toolkit Manual Inter-Municipal Cooperation, Strasbourg.

- de Bruycker, P. (2000), La coopération intercommunale en Belgique, Annuaire 2000 des collectivités locales. La reforme de l'intercommunalité, CNRS Éditions, Paris.

- Danielewicz, J. (2013), 'Cooperation of communes in metropolitan areas in the

Malgorzata OFIARSKA, Journal of Eastern Europe Research in Business and Economics, DOI: $10.5171 / 2022.349212$ 
framework of inter-communal association', Research Papers of Wrocław University of Economics, 284, 114-131.

- Dollery, B., Kitchen, H., McMillan, M. and Shah, A. (2020), Intermunicipal Cooperation, Local Public, Fiscal and Financial Governance. An International Perspective, Dollery, B. et al. (eds.), Palgrave Macmillan, Cham.

- Dolnicki, B. (ed.) (2018), Formy współdziałania jednostek samorządu terytorialnego, Wolters Kluwer, Warszawa.

- Endlich, A. (2018), Cooperações intermunicipais em áreas nãometropolitanas', Redes, 23 (3), 95116.

- Font i Llovet, T. (2000), La cooperation intercommunale en Espagne, Annuaire 2000 des collectivités locales. La reforme de l'intercommunalité, CNRS Éditions, Paris.

- Fraanje, R. and Herweijer, M. (2013), 'Innoveren in samenwerking: een alternatief voor herindeling?, Bestuurswetenschappen, 3/3, 5876.

- Gendźwiłł, A., Krukowska, J. and Lackowska, M. (2019), 'Disappointment or unexpected gain? A survey-based study of the motives and outcomes of intermunicipal cooperation in Poland, Miscellanea Geographica Regional Studies on Development, 23 (4), 235-241.

- Girardon, J. (2008), L'intercommunalité, Ellipses, Paris.

- Grešová, L. (2016), 'Towards the Implementation of the Best Practice from Abroad Strengthening the Cooperation Among Slovak Municipalities', Acta Regionalia et Environmentalica, 2, 35-40.

- Groud, H. (2003), Reflexions sur la cooperation et les regroupements intercommunaux en Allemagne, Decentralisation intercommunalité en France et en Europe, Nemery, J.C. (ed.), Editions L'Harmattan, Paris.

- Haaren-Dresens, I. V. (2000), La coopération intercommunale aux Pays-Bas, Annuaire 2000 des collectivités locales. La reforme de l'intercommunalité, CNRS Éditions, Paris.

- Hertzog, R. (2010), Inter-municipal co-operation: A viable alternative to territorial amalgamation?, Territorial consolidation reforms in Europe, Swianiewicz, P. (ed.), OSI/LGI, Budapest.

- Hilborn, I. and Riberdahl, C. (2000), Kommunala samverkansformer: avtal, internkommunala företag, gemensam nämnd, kommunalförbund, Svenska Kommunförbundet, Stockholm.

- Hulst, J.R. and van Montfort, A.J.G.M. (2007), Inter-municipal cooperation in Europe, Springer, Dordrecht.

- Hulst, J.R. and van Montfort, A.J.G.M. (2012), 'Institutional Features of Inter-Municipal Cooperation: Cooperative Arrangements and their National Contexts', Public Policy and Administration, 27(2), 121-144.

- Jaworska-Dębska, B. (2017), 0 istocie związków metropolitalnych, 0 prawie administracyjnym i administracji. Refleksje. Księga jubileuszowa dedykowana Profesor Małgorzacie Stahl, Jaworska-Dębska, B. (ed.), Wydawnictwo Uniwersytetu Łódzkiego, Łódź.

- Jaworska-Dębska, B. (2019), Współdziałanie jednostek samorządu terytorialnego w wybranych formach publicznoprawnych a ich samodzielność, Decentralizacja i centralizacja administracji publicznej: współczesny wymiar w teorii i praktyce, Jaworska-Dębska, B., Olejniczak-Szałowska, E. and

Malgorzata OFIARSKA, Journal of Eastern Europe Research in Business and Economics, DOI: $10.5171 / 2022.349212$ 
Budzisz, R. (eds.), Wolters Kluwer, Warszawa-Łódź.

- Ježek, J. and Kaňka, L. (2015), Mezi slučováním obcí a meziobecní spoluprací: meziobecní spolupráce jako alternativa ke slučování obcí?, Spolupráce obcí a měst - České a evropské přístupy ke slučování obcí a meziobecní spolupráci, Ježek, J., Malast, J., Kopecký, M., Kaňka, L., Západočeská univerzita, Plzeň.

- $\quad$ Kiełbus, M. and Ziemski, K. (2020), 'Ewolucja publicznoprawnych form współpracy jednostek samorządu terytorialnego`, Samorząd Terytorialny, 4, 82-96.

- Kogut-Jaworska, M. and Smalec, A. (2018), Partnerstwo i komunikacja w samorządzie terytorialnym: wybrane aspekty zarządzania i finansowania, edu-Libri, Kraków.

- Kołsut, B. (2015), Zinstytucjonalizowane sieci współdziałania międzygminnego w Polsce, Bogucki Wydawnictwo Naukowe, Poznań.

- Koprić, I., Škarica, M. and Milošević, B. (2015), Suradnja i razvoj u lokalnoj i regionalnoj samoupravi, Institut za javnu upravu, Zagreb.

- Kotlińska, J. (2017), ‘Formy współpracy jednostek samorządu terytorialnego i ich wykorzystanie w praktyce', Finanse Komunalne, 9, 19-30.

- Kurti, O. and Lame, E. (2014), 'Inter-Municipal Cooperation as an Alternative to Public Service Delivery in Albania', Belgium Volume: Policy Series, 11, 1-12.

- Lisowski, P. (2017), Nowe typy związków samorządowych w Polsce na przykładzie związków powiatowo-gminnych, Sposoby realizacji zadań publicznych, Dolnicki, B. (ed.), Wolters Kluwer, Warszawa.
- $\quad$ Łukomska, J. and Szmigiel-Rawska, K. (2019), 'Inter-local relations and trans-scaling through finance in Poland, Journal of Economic Policy Reform, 22(2), 184-201.

- Mäeltsemees, S., Lõhmus, M. and Ratas, J. (2013), 'Inter-municipal cooperation: Possibility for Advancing Local Democracy and Subsidiarity in Estonia', Halduskultuur - Administrative Culture, 14 (1), 73-97.

- Marotta, M., Bolgherini, S. and Casula, M. (2018), Il dilemma del riordino. Unioni e fusioni dei comuni italiani, Il Mulino.

- Matschek, M. (2011), 'Interkommunale Zusammenarbeit (IKZ)', Schriftenreiherecht \& Finanzenfur Gemeinden, 2, 11-94.

- Montalvo, A. (2020), La coopération intercommunale au Portugal, Annuaire 2000 des collectivités locales. La reforme de l'intercommunalité, CNRS Éditions, Paris.

- Ofiarska, M. (2008), Formy publicznoprawne współdziałania jednostek samorządu terytorialnego, Wolters Kluwer, Warszawa.

- $\quad$ Ofiarska, M. (2017), Supervision of the Metropolitan Union's Financial Issues in Poland, Acta Universitatis Brunensis. Iuridica, Editio Scientia, 580, 156-171.

- Ofiarska, M. (2018), 'Kształtowanie się koncepcji związku metropolitalnego w Polsce po 1990 roku', Acta Universitatis Wratoslaviensis. Przegląd Prawa $i$ Administracji, 114, 351-369.

- Ofiarska, M. (2020), `Ewolucja regulacji prawnych stanowiących podstawy współdziałania w samorządzie terytorialnym $\mathrm{w}$ okresie 30-lecia samorządu terytorialnego w Polsce', Samorząd Terytorialny, 4, 29-51.

- Ofiarska, M. and Ofiarski, Z. (2021), Związki komunalne

Malgorzata OFIARSKA, Journal of Eastern Europe Research in Business and Economics, DOI: $10.5171 / 2022.349212$ 
metropolitalne w Polsce, Wolters Kluwer, Warszawa 2021.

- Perrin, B. (2001), La coopération intercommunale, Berger-Levrault, Paris.

- Pevcin, P. (2018), 'The Analysis of the Implementation of municipal Cooperation and Merger Strategies: Case Study for Slovenia', Economics and Culture, 15(1), 15-21.

- Popova, Y. and Kononenko, M. (2018), 'The modern state and prospects for the development of inter-municipal cooperation', Modern Economics, 10, 97-101.

- Rakar, I., Tičar, B. and Klun M. (2015), 'Inter-municipal cooperation: challenges in Europe and in Slovenia', Transylvanian Review of Administrative Sciences, 45 (E 2015), 185-200.

- Rakar, I., Tičar, N. and Klun M. (2014), 'Territorial Changes to Municipalities and Inter-Municipal Cooperation: A Comparative Overview and Orientations for Slovenia', Lex Localis - Journal of Local Self-Government, 12/3, 731748.

- Rolfes, S., Volkert, W. (1992), Aufgaben und Organisation der öffentlichen Verwaltung, Boorberg, Stuttgart.

- Sancton, A., James, R. and Ramsay, R. (2000), Amalgamation vs. intermunicipal cooperation: financing local and infrastructure services, ICURR Press, Toronto.

- Sedmihradská, L. (2018), 'InterMunicipal Cooperation in the Czech Republic: A Public Finance Perspective', The NISPAcee Journal of Public Administration and Policy, XI/2, 153-170.

- $\quad$ Spicer, Z. (2015), 'Cooperation and Capacity: Inter-Municipal Agreements in Canada', IMFG Papers on Municipal Finance and Governance, 19, 1-31.

- Stehen, T., Wayenberg, E. (2016), Explaining Trajectories of Municipal Amalgamations: A Case
Comparison of the Netherlands and Flanders Wout Broekema, Local Public Sector Reforms in Times of Crisis. National Trajectories and International Comparisons, Kuhlmann, S. and Bouckaert, G. (eds.), Palgrave Macmillan, London.

- Steiner, R. (2001), Collaboration intercommunale et fusion de communes en Suisse, Gouvernance locale, coopération et légitimité Le cas suisse dans une perspective compare, Leresche, J.P.(ed.), Pedone, Paris.

- Steiner, R. (2002), Interkommunale Zusammenarbeit und Gemeindefusionen in der Schweiz. Ergebnisse einer empirischen Studie und Ansätze für ein systematisches Kooperations- und Fusionsmanagement, Bern Stuttgart - Wien.

- Steiner, R. (2006), 'Interkommunale Zusammenarbeit in der Schweiz', Sir-Mitteilungen und Berichte, 32, 53-64.

- Swianiewicz, P. (ed.) (2011), Working together: intermunicipal cooperation in five Central European Countries, Open Society Foundations, Budapest.

- Swianiewicz, P. and Teles, F. (2019), 'The Institutionalization of Inter-Municipal Arrangements in Europe: Findings from the Unusual Suspects', Transylvanian Review of Administrative Sciences, 15 (57E), 119-136.

- $\quad$ Swianiewicz, P. and Teles, F. (eds.) (2018), Intermunicipal Cooperation in Europe. Institutions and Governance, Palgrave Macmillan, New York.

- Szczegielniak, M. (ed.) (2017), Współdziałanie jednostek samorządu terytorialnego w Polsce: między kooperacją a rywalizacją, Elipsa, Warszawa.

- Szlachetko, J.H. and Gajewski, R. (2016), Instytucjonalne formy współdziałania jednostek 
samorządu terytorialnego na obszarach metropolitalnych, Wydawnictwo Uniwersytetu Gdańskiego, Gdańsk.

- Tavares, A.F. and Feiock, R.C. (2018), `Applying an Institutional Collective Action Framework to Investigate Intermunicipal Cooperation in Europe', Perspectives on Public Management and Governance, 1/4, 299-316.

- Teles, F. (2016), Local Governance and Inter-municipal Cooperation, Palgrave Macmillan, Basingstoke.

- Thurmaier, K. and Wood, C. (2004), Interlocal agreements as an alternative to consolidation, City-county consolidation and its alternatives. Reshaping the local government landscape, Carr, J.B. and Feiock, R.C. (eds.), Routledge.

- Tolkovanov, V.V. (2017), 'Territorial Communities' Cooperation (Intermunicipal Cooperation - IMC) as an innovative tool for ensuring local economic development and municipal consolidation', Scientific Bulletin of Polissia, 1, 76-80.

- Warner, M., Austin, A. and Yunji, K. (2020), 'Privatization and intermunicipal cooperation in US local government services: balancing fiscal stress, need and political interests', Public Management Review, 4, 1-18.

- Wollmann, H. (2017), 'Les réformes du système local dans les länder allemands: entre communes fusionnées et intercommunalité, Revue française d'administration publique, 162, 313-326.

- Yurisch A.K., Soto, K. and Fuenzalida, C.R. (2019), 'Intermunicipal cooperation in Latin America: current situation and future research challenges', Revista de Administração Pública, 53(3), 575-591.

- Zeman-Miszewska, E. (2016), 'Local governments' dimensions of cooperation with externale entities', Studia i Prace Wydziału Nauk Ekonomicznych i Zarzq̨dzania, 44, 285-300.

- Zielke, B. (1993), Zwischengemeindliche Zusammenarbeit. Rechtliche, organisatorische und finanzielle Gestaltungsmöglichkeiten, Erich Schmidt Verlag GmbH, Berlin.

- Zioło, M. and Oliwa, B. (2016), 'Organizacja i funkcjonowanie związków międzygminnych w Polsce`, Współczesne Finanse. Teoria i praktyka,1, 123-134.

Malgorzata OFIARSKA, Journal of Eastern Europe Research in Business and Economics, DOI: $10.5171 / 2022.349212$ 